\title{
Stakeholder participation in flood control of Ciliwung river, Jakarta, Indonesia
}

\author{
A. Neolaka \\ Department of Civil Engineering, Faculty of Technology, \\ State University of Jakarta, Indonesia
}

\begin{abstract}
This study aims at investigating the level of participation in flood control activities on the part of community members who live by the Ciliwung river bank. Since the river is quite a long one, it was decided to conduct this study in the area between Kalibata Bridge and Manggarai floodgate, about eight kilometers in length. The study was conducted between October to December 2011.

The study focused on natural resources management. The first sub-focus is stakeholder participation, the second is flood control, and the third is the Ciliwung river bank area where recurrent flood occurs. The study questions whether there is community participation in flood control activities within the Ciliwung riverbank area. The paradigm is how the government, together with the community along the Ciliwung riverbank, demonstrate their concern for their environment that is reflected in their taking care of the environment such as preventing themselves from throwing garbage into the river so as not to flood every time it rains. This qualitative study is supported by data collected by means of observations, interviews, and documentation.

Findings of the study show a high level of participation expressed in words by the community. Yet, they reported difficulties in putting this into action due to the slum area they are living in, unavailability of road access, and waste resulting from disposal activities of residents forced to use the river. It is therefore not surprising that the river is full of garbage and they experience floods during the rainy season. The government has not sufficiently persudaded the target community to participate in flood control activities. In interviews, the target community stated that they were ready not to throw garbage into the river provided that there is road access, garbage carts or trucks are available for
\end{abstract}


transporting waste to landfill. We are ready to move from the Ciliwung riverbank areas, where we have lived after our predecessors, provided that a decent substitute place is made available, or some compensation that allows us a decent living is rendered by the government. In fact, the government is planning to normalize the Ciliwung riverbanks and prepare inexpensive flats for the community.

In conclusion, the community is willing to participate by not throwing garbage into the river so that the flooding could be controlled, provided that the government be proactive with their assistance by providing road access and waste transport along the Ciliwung riverbanks. Otherwise, the flood problem cannot be controlled.

Keywords: stakeholders, participation, flood control, Ciliwung river.

\section{Introduction}

Ciliwung river is well known to all citizens of Jakarta. It always becomes a hot topic in the rainy seasons as it is the main source of floods in Jakarta. The Ciliwung is approximately 170 kilometres in length, stretched from the border of Bogor and Cianjur, or around the Puncak area, where it starts, and flows down north, passes Depok, South and East Jakarta areas, and, finally, enters the Java Sea. The history of Ciliwung began 6 (six) million years ago. In the 1900s, the European settlers viewed the river as "a paradise in the tropical hemisphere" for it was beautiful, relatively wide, and allowed small boats to transport merchandise within the downstream area [1]. In other words, its older picture was contradictory compared to that of present society. The Ciliwung riverbanks is currently considered as the source of recurring problems to DKI Jakarta Provincial Government. In Manggarai area, the river is very much manipulated for flood control purposes. TheWest Flood Canal has been constructed, directing the river flow to the west, then to north, passing Tanah Abang, Tomang, Jembatan Lima, to Pluit area. Similarly, the East Flood Canal has been constructed, directing the river flow from East Jakarta, passing the Duren Sawit, Pondok Kopi and Cakung areas, heading to North Jakarta, or to the sea. There are 13 (thirteen) rivers that flow into Jakarta. Yet, Ciliwung poses the most extensive impact on the city when the rainy season comes. It is because it flows through the central area of Jakarta, passing many slum areas. The river is also considered the worst environmentally deformed compared to others in Jakarta.

\section{Discussion of the study}

Discussion of the study is important in finding out about stakeholders participation in the Ciliwung riverbank flood control activities. Stakeholders participation can be observed in their daily living practices. In addition, it is also important to find out information on local government practices in helping the 
Ciliwung riverbank community to survive the annual flood disaster. What has the local government do in preparing inexpensive housing for this target community?

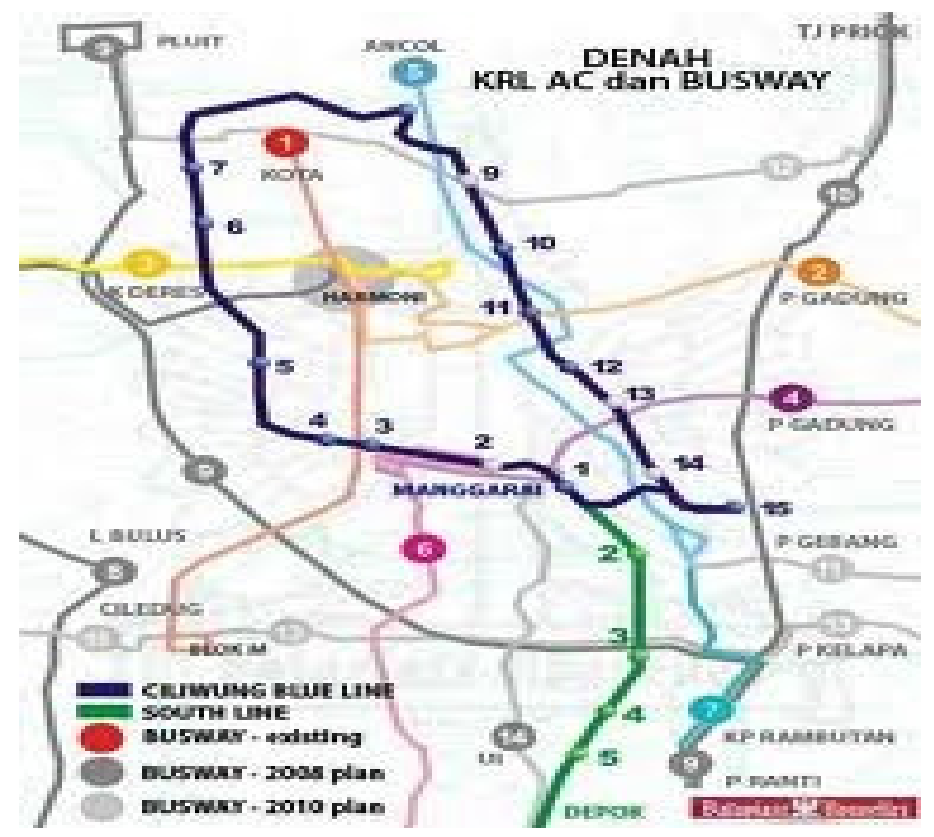

Figure 1: $\quad$ Map of the Ciliwung research site.

\subsection{Purpose of the study}

This study aims at obtaining in depth insights on stakeholders participation in the Ciliwung riverbank flood control activities. Their participation can be observed from the level of awareness of the needs to take care of the environment along the river, prevent disposing waste into the river, and find a more comfortable living place. Flood disaster occurs annually; thus, it is important to understand how the respective community and the local government respond to the Ciliwung riverbank community living condition in the event of flood.

\subsection{Methodology}

This qualitative study is supported by data collected by means of observations, interviews, and documentation. It aims at finding answer to the question. Does community participation exist in the Ciliwung riverbank flood control activities performed in the object area of the study? 'Population of the study consists of the whole area of Ciliwung riverbank within Jakarta city, excluded those outside the 
city. Samples of the study include Ciliwung riverbanks area between Kalibata Bridge and Manggarai floodgate, about eight kilometers in length. Respondents in interviews were residents of Kampung Pulo RT 13 and RT 14/RW 02, Jatinegara, Kampung Melayu, East Jakarta.This sample was chosen because along its banks are filled with garbage, the daily activities of citizens, such as, bathing, washing clothes, and disposing of sewage/latrine. The study was conducted between October to December 2011. The study focuses on natural resources management. The first sub-focus is community participation, the second is flood control, and the third is the Ciliwung riverbanks area where recurrent flood occurs. Instruments of the study include the researcher himself who collected data by means of observations, interviews and documentation. Critical qualitative data analysis was employed that resulted in data matrix and presentation where possible.

\subsection{Findings of the study}

\subsubsection{Description of data}

First of all, let us observe current data on an increase in Ciliwung river discharge resulting from continuous rain. Data of the National Radio News(KBRN) Friday, January 13, 2012, states that the Ciliwung river discharge has increased, and citizens are concerned about the 5-year cycle of flooding. Suryadarma Tarigan, from Bogor Agricultural University [2], states that: the conditions in the upstream of Ciliwung in Puncak, Bogor, West Java, has been deteriorating in the last ten years due to the rapid growth of settlements. This could potentially lead to greater floods even at similar rain fall level that has brought by the 2002 or 2007 flood. It was said, because at normal conditions Ciliwung river flooding that occurred in 2002 and 2007, making some areas of the city flooded as high as $1.5-3$ meters. It is because the Ciliwung upstream condition was normal at the 2002 and 2007 flood events, yet, it brought flood with a 1.5-3 meters height in Jakarta.

Table 1: Ciliwung discharge from Puncak, Bogor.

\begin{tabular}{|c|c|c|c|c|c|}
\hline \multirow[b]{2}{*}{ Year } & \multicolumn{5}{|c|}{$\Sigma$ water } \\
\hline & Average & $\begin{array}{c}\text { Highest } \\
\text { debit }\end{array}$ & $\begin{array}{c}\text { Lowest } \\
\text { debit }\end{array}$ & $\begin{array}{c}\text { Highest } \\
(\%)\end{array}$ & $\begin{array}{c}\text { Lowest } \\
(\%)\end{array}$ \\
\hline $\begin{array}{c}2002- \\
2006\end{array}$ & $\begin{array}{c}4.28 \\
\mathrm{~m}^{3} / \mathrm{sec}\end{array}$ & $\begin{array}{c}43.10 \\
\mathrm{~m}^{3} / \mathrm{sec}\end{array}$ & $\begin{array}{c}11.98 \\
\mathrm{~m}^{3} / \mathrm{sec}\end{array}$ & 907.01 & 179.60 \\
\hline 2002 & \multicolumn{5}{|c|}{ This year flood made Jakarta a pool of water } \\
\hline 2007 & \multicolumn{5}{|c|}{ Flood, five years later, made Jakarta looked like an ocean } \\
\hline
\end{tabular}

Source: Kompas, 2011/11/15. 


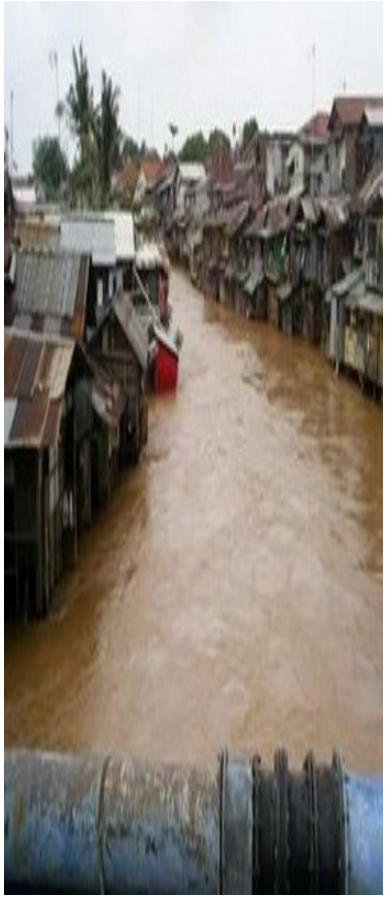

Figure 2:
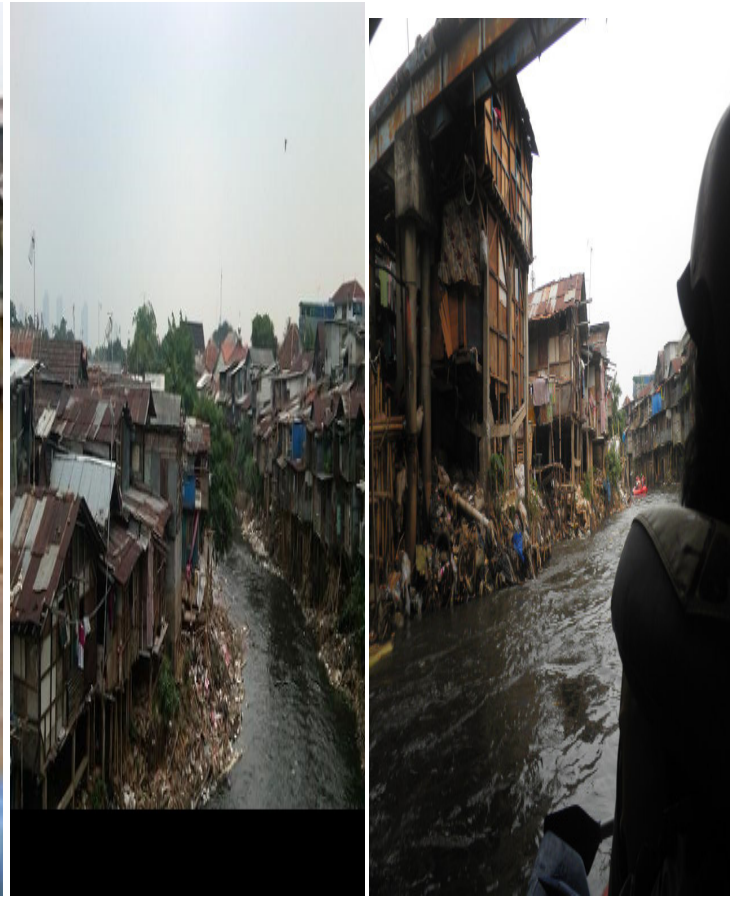

Ciliwung water discharge increases.

Table 2: Land condition and status of the Ciliwung riverbanks inhabitants.

\begin{tabular}{|c|c|c|c|}
\hline ResidenceTime & Land Status & Tax Payment & $\begin{array}{c}\text { Residential } \\
\text { Permit }\end{array}$ \\
\hline $\begin{array}{l}\text {-Very long, } \\
\text { since colonial } \\
\text { time }\end{array}$ & -Proprietary & -Taxpayer & $\begin{array}{c}\text {-Not } \\
\text { required }\end{array}$ \\
\hline $\begin{array}{l}\text {-Over } \\
\text { generations }\end{array}$ & -Family & $\begin{array}{l}\text {-Predecessors } \\
\text { property } \\
\text { taxpayers }\end{array}$ & $\begin{array}{c}\text {-Parents' } \\
\text { Proprietary }\end{array}$ \\
\hline $\begin{array}{c}\text {-Over } \\
\text { generations }\end{array}$ & -Ancestral & & -Proprietary \\
\hline
\end{tabular}

Source: Research findings data

\subsubsection{Residents perception}

A number of residents stated that they were already submissive to the existing conditions. Although there is a desire to move, it is not clear where they should go. Years of experience in coping with floods have finally made them used to the 
condition and accept it as it is. Everytime the rainy season arrives, Ciliwung is always on alert for floods because continuous rain in the greater Jakarta area will results in overflows of Ciliwung. The Ciliwung overflow frequently covers up residential areas in RW 3, Kampung Pulo, East Jakarta. Residents are often forced to live on the top floor of their home as flood water reaches a height of 1.5 meters. Some residents choose to flee in fear of greater flood level. They often use rafts as a means of transport, considering condition of the water which is excessively dirty mixed with waste. The table below presents their opinions in more details.

Table 3: Opinions of Ciliwung riverbanks residents.

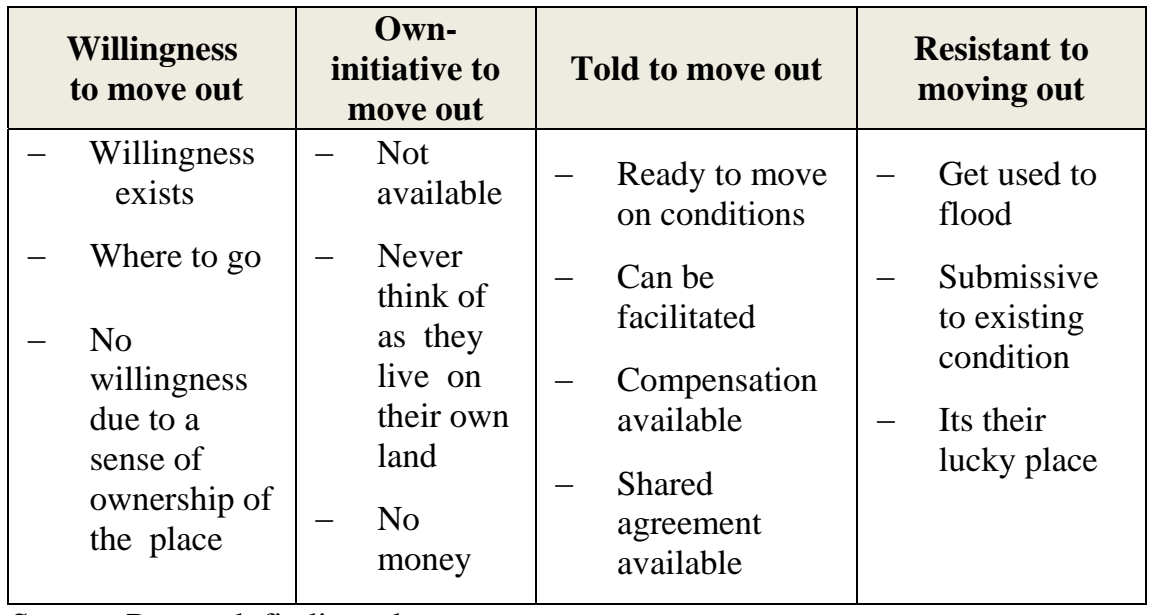

Source: Research findings data.

2.3.2.1 Participation of Stakeholders of Ciliwung riverbanks Participation is the one's conscious involvement in social interactions in specific situations. Saca Firmansyah [3] suggests that participation is the conscious active involvement of a person or group of people (society) to voluntarily contribute in a development program, from the planning phase, to implementation, up to the evaluation stage [3]. Whereas, according to Isbandi [4, p 27], community participation covers involvement in the identification process of existing problems and potentials in the community, the selection and decision-making for alternative solutions to the problems, the problem solving implementation, and the evaluation of occuring changes [4]. There are several factors that can influence community participation in a program. According to Angell (in Ross [5, p 130]), participation that grows within a society is influenced by:(1) age, those in middle age group and beyond, (2) sex, in this case, female, as a result of emancipation, (3) education, is considered influential to one's attitudes towards the environment, (4) employment and income, ones that satisfactorily and sufficiently help in meeting the daily needs can encourage people to participate in community activities, and (5) length of stay, the longer one stays in a particular environment, the greater his/her sense of ownership of the 
environment, and the more visible and greater his/her participation in any activity that environment [5].
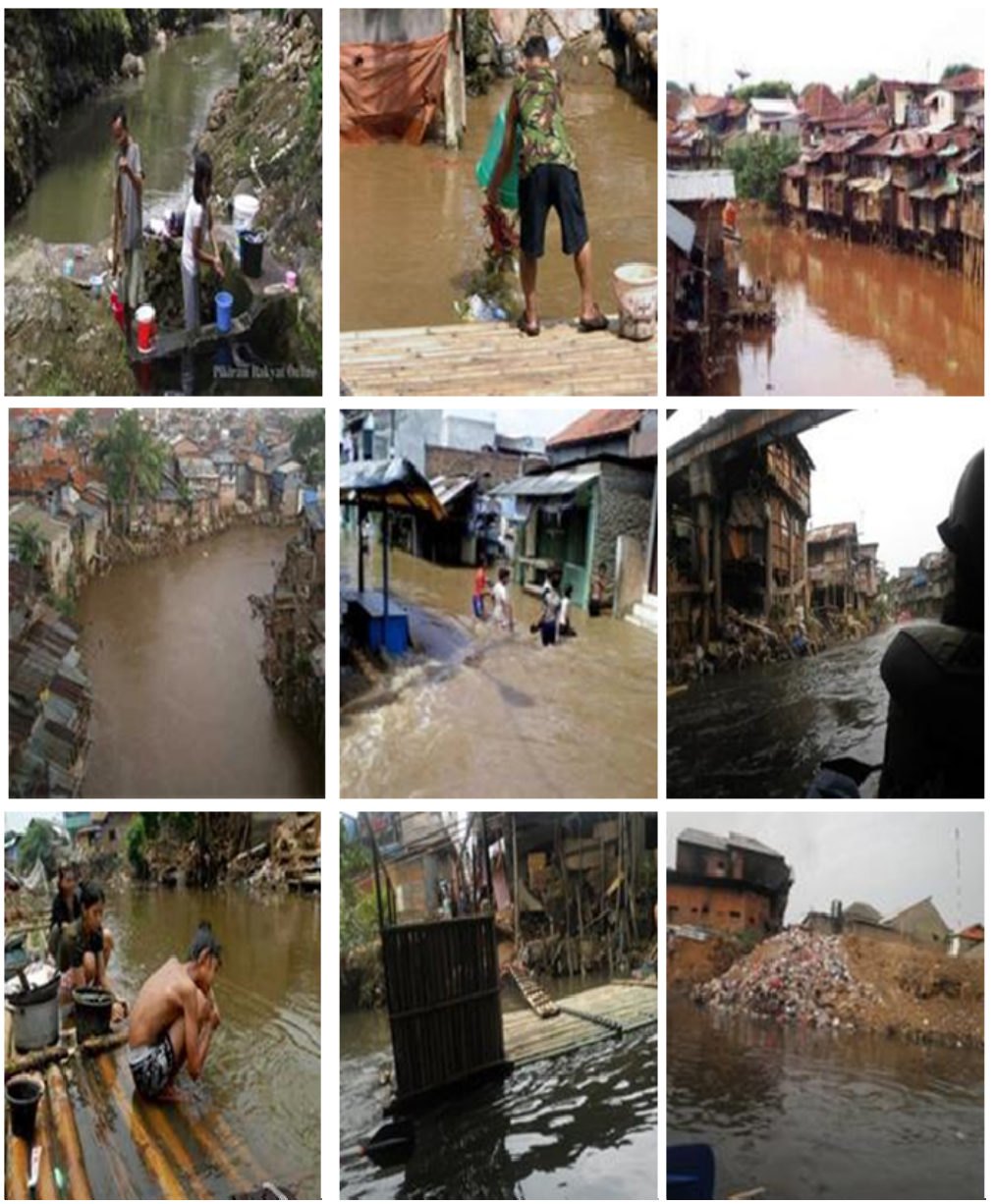

Figure 3: Residents' activities (disposing garbage, washing clothes, taking a bath, brushing teeth). Source: Research survey findings.

Based on the above participation theories, the emerging question would be 'How is the participation of stakeholders in the Ciliwung riverbanks?' The observation study, performed by tracing the river from Kalibata to Manggarai flood control gate, which is approximately eight kilometres in length, offers some findings that indicate a lack of participation of stakeholders/communities in flood control activities. It is due to the following evidence found in the area in question: there is a variety of garbage piled up or buried along the riverbanks, the river is dirty, blackish in color and smelly, and there are people living under the river bridges. They threw garbage into the river, sent sewage(from bathing, 
washing, toilets) to the river with no guilty feeling, and even had public toilets in the middle of the river. Government efforts to encourage community participation in flood control seem to be insufficiently responded by the Ciliwung riverbanks community. This may be due to the fact that government efforts are just an appeal to the people for not living in the Ciliwung riverbanks. Based on data from observations and interviews, particularly in Kampung Pulo RT 13 and RW 02, Jatinegara - Kampung Melayu, the residents stated that they would not mind relocatedfrom their current residence. It means that it is possible to relocate the riverbanks residents, provided that the government prepare the new place for them. The residents also stated that they had been living on the site for generations, they feel like they were the land owner, and the riverbanks is theirs as well. So, it is not possible for them to move to another place without any coompensation for their current residence.

2.3.2.2 Condition of Ciliwung riverbanks Riverbanks is the land on both sides along a riverbed, from the river edge to the inner foot of the river embankment. This area is supposed to be a green-belt area rather than a residential one.In this way, it can function as water catchment area that should cover a distance of about half a mile $(0.5 \mathrm{~km})$ from the river border. One thing that we can observe on this riverbanks is the many people who consider this place as their home or residence. About 71 thousand people live here, occupying about 14 thousand houses. Surprisingly, we can observe that they can make use of the river for their daily needs. Housewives and their family use the river for washing clothes, bathing and toilet. The kids play and swim with their playmates. And, the fathers also use water from the river for ablution before praying [6]. Another physical finding is the fact that the river is reducing in width and depth, stage-houses stand along the riverbanks, piles of garbage along the river signifies its functioning as a rubbish tip. There are many illegal settlements, houses along the riverbank slum. A river with dirty, blackish and smelly water, full of rubbish. There are also people living under the river bridges.

A number of the residents still have access to clean water and electricity from the government. In time of floods or over flowing river, they become the first exposed to the flood. The flood enters their houses, carrying a variety of incredibly filthy content of the river, and cover their houses to the roof with 3-4 meter high flood. This incident is a "routine" the people must deal with every rainy season. Therefore, being used to the flood has made it no longer a burden for them to live on the riverbanks.

People who use water from the river are the riverbanks inhabitants. Residents in this area indicate a practice of using streams and rivers to defecate, as well as brushing their teeth and washing their eating utensils. On the other hand, eating raw vegetables is one of their favorite things. This means that washing vegetables using water from the river is not hygienic.They can get infected with helminthic. The fact that there are still many people go to the river for defecating, and even build public toilets at the river, only shows their lack of awareness that the river can be source of transmission of various diseases. Data from field surveys indicates that population along the Ciliwung riverbanks, is 
very alarming, because the place is really a slum area. There are houses with ragged plywood and wood walls. Houses on stilts stand with no distance from each other, the river flows right underneath, blackish in color resulting from a mixture of thick dirt, garbage and solid waste. Yet, they are already very familiar with the situation. In fact, they wash their household appliances in the river, sit at the public toilet to answer the call of nature, have no care of their surroundings. There are children bathing in the dirty, polluted and smelly river that is full with abundant garbage.

Table 4: Physical condition of Ciliwung at the time of the study.

\begin{tabular}{|l|l|l|}
\hline \multicolumn{1}{|c|}{ River Width } & River Depth & $\begin{array}{c}\text { Waste Thickness and } \\
\text { Distance Between Houses } \\
\text { To Riverbanks }\end{array}$ \\
\hline$-\begin{array}{l}\text { Initially it was } \pm 60 \\
\text { meter }\end{array}$ & $-\begin{array}{l}\text { Initially it was } \\
\pm 15 \text { meter } \\
\text { Currently it is } \pm 15 \\
\text { meter }\end{array}$ & $-\begin{array}{l}\text { Initially the water was } \\
\text { Clean with no } \\
\text { trash/waste }\end{array}$ \\
$-\begin{array}{l}\text { Narrowing in width it is } \\
\text { due to housing } \\
\text { construction that } \\
\text { goes further to the } \\
\text { river area and } \\
\text { emerging new land } \\
\text { of garbage } \\
\text { sedimentation }\end{array}$ & $-\begin{array}{l}\text { River bed is } \\
\text { never dredged } \\
\text { out for mud \& } \\
\text { rubbish }\end{array}$ & $-\begin{array}{l}\text { Initially the water is } \\
\text { dirty, blackish, with } \\
\text { trash/wasteof } \pm 3 \\
\text { meter in thickness } \\
\text { No distance between } \\
\text { housing and the river }\end{array}$ \\
\end{tabular}

Source: Research findings data.

Table 5: Behaviour of the Ciliwung riverbanks stakeholders.

\begin{tabular}{|c|c|c|}
\hline $\begin{array}{c}\text { Garbage Disposing } \\
\text { Behavior }\end{array}$ & $\begin{array}{c}\text { Washing At The River } \\
\text { Behavior }\end{array}$ & Health Care Behavior \\
\hline$-\begin{array}{l}\text { Throwing garbage } \\
\text { into the river }\end{array}$ & $-\begin{array}{l}\text { Cleaning rice for } \\
\text { cooking }\end{array}$ & $-\begin{array}{l}\text { Taking bath in the } \\
\text { river }\end{array}$ \\
\hline $\begin{array}{l}\text { All kinds of waste } \\
\text { are thrown into } \\
\text { the river }\end{array}$ & $-\begin{array}{l}\text { Cleaning } \\
\text { vegetables }\end{array}$ & $-\begin{array}{l}\text { Brushing teeth in } \\
\text { the river }\end{array}$ \\
\hline$-\begin{array}{l}\text { Domestic sewage } \\
\text { is directed into the } \\
\text { river }\end{array}$ & $-\begin{array}{l}\text { Washing dishes and } \\
\text { cuttleries } \\
\text { Washing clothes }\end{array}$ & $-\begin{array}{l}\text { Building toilets and } \\
\text { bathrooms in the } \\
\text { river } \\
\text { Defecating into the } \\
\text { river }\end{array}$ \\
\hline
\end{tabular}

Source: Research findings data. 
2.3.2.3 Flood control performed by stakeholders of the riverbank Indeed, life in Jakarta offers tight competition across the years. This also applies to people living in Ciliwung riverbanks. They consist of migrants who seek their luck in the city and the natives who live there for generations and perceive the place as theirs. They need to be aware of the fact that the main source of flood in Jakarta that trigger Ciliwung to overflow is the garbage scattered all over the rivers. This garbage creates a block to the river stream and lead the river to overflow. The majority of people living in Ciliwung riverbanks are belong to the poor. Therefore, there is no chance for them to consider flood control efforts. Actually, it is enough for them not throwing garbage into the river. This is the only thing they need do as a form of participation in flood control activities.Thus, there is a need for realaction on the part of the government to help prevent the people in from throwing garbage into the river. The strategy should not use the form of an appeal, but harmonious communication through counselling for residents along the riverbanks. The main point is to show care for them by providing them with the values of a decent life. The government can not immediately relocate them to other place since they already live there for generations and consider the land their property. Based on the research observation data, the people are willing to move to other place. Yet, there is a need to come to a shared agreement on a compensation that will allow them a sustainable live. According to Neolaka, awareness for not throwing garbage into the river but to the provided place becomes important to be developed in the Ciliwung riverbanks community as a value of life [7].

\subsubsection{Efforts to encourage participation of the riverbank} stakeholders Current effort of the government is normalization of Ciliwung. Normalization is the act of making a normal return, i.e. the action returns an object to its original state [8]. In the case of Ciliwung, it is the act to restore the river to its original state: a clean,beautiful river. This requires dredging out mud and rubbish from the river, construct strong walls on both river sides, and relocate the riverbanks residents. This should be done, obviously, in a good and harmonious way. Substitute land should be made available, flats need to be prepared for them on free, rental or purchase scheme. In reality, many people refused to move to the assigned place because they do not come in terms about the offered compensation. Community participation expected by the government means willingness of the people to be relocated to the place provided; i.e. is flats for inexpensive rent or free for the disadvantaged people. Based on observations data, the community is willing to participate by moving out to another place. Yet, the government's failure in disseminating the Ciliwung normalization plan has been a disadvantage. In other words, there is a need for a harmonious realtionship with the community, through education that can develop a mindset that keeps in search for a life better than today's.We do not always require verbal language. Rather, a language of behaviour is needed. This means that community participation should not only be in words but in real actions. 


\section{Conclusion}

To sum up, the Ciliwung riverbanks community have the willingness to participate in the flood control activities by not throwing garbage into the river so that flooding could be controlled. However, the government are required to be proactive in facilitating their needs to participate by providing road access and garbage transport for the Ciliwung riverbanks area. Else, flood problems would not be in control. The government can begin to be proactive to help the riverbanks stakeholders or community by performing normalization of the Ciliwung river. One normalization effort is to build free or inexpensive rental housing project for the economically disadvantaged people. As a matter of fact, the riverbanks community refused to move to the place provided by the government for it does not comply with the agreed compensation scheme. Thus, there is a need for harmonious communication between the government and the Ciliwung riverbanks stakeholders. This can be done through an education program that can develop a mindset that keeps in search for a life better than today's.

\section{References}

[1] http://id.wikipedia.org/wiki/ci_liwung/2011/25/10.

[2] Surya Dharma, http://pr operti.kompas.com/read/2011/11/15.

[3] Saca Firmansyah (http://sacafirmansyah.wordpress.com/2009/06/05).

[4] Isbandi Rukminto Adi. Participatory Planning Based on Community Assets: From Thoughts Towards Implementation. Depok: FISIP UI Press, pp. 2731, 2007.

[5] Ross, Murray G., and B.W. Lappin. Community Organization: theory, principles and practice. Second Edition. New York: Harper \& Row Publishers, p.116, 1967.

[6] http://www.anneahira.com/bantaransungai/htm/2011/23/10.

[7] Neolaka, Amos. Environmental Awareness. Jakarta: Rineka Cipta, pp. 7478, 2008.

[8] Neolaka, Amos. Normalization of the Ciliwung River. Jakarta: Jurusan Teknik Sipil FT UNJ, p.11, 2011. 